\title{
Toward Fluorinated Aminoglycosides: Structural Studies of Phenylhydrazine Condensation with Carbohydrate Derivatives
}

\author{
Antonio Franconetti,* Pastora Borrachero, Manuel Gómez-Guillén, Francisca Cabrera-Escribano* \\ Departamento de Química Orgánica, Facultad de Química, Universidad de Sevilla, Apartado de Correos No. 1203, 41071 Sevilla, Spain \\ Fax+34(95)4624960; E-mail: afranconetti@us.es; E-mail: fcabrera@us.es \\ Received: 28.10.2012; Accepted: 15.11.2012
}

\begin{abstract}
The reaction of phenylhydrazine with a sugar dialdehyde in water, as a key step for the synthesis of the 3-amino-3-deoxy-Dglucose moiety contained in kanamycin, has been revisited. Structural studies (IR and NMR as well as a simple theoretical model based on energy-minimization calculations and MD calculations) reported herein support the observed stereo- and regioselectivity. Efforts to improve the reproducibility and viability of the process as part of a convenient approach towards fluorinated kanamycin are also now presented.
\end{abstract}

Key words: carbohydrates, condensation, phenylhydrazine, stereoand regioselectivity, green chemistry

Aminoglycosides are the most commonly used antibiotics worldwide thanks to the combination of their high efficacy with low cost. These compounds act on gram-positive and gram-negative bacteria as protein synthesis inhibitors. ${ }^{1}$ However, they are nephrotoxic and ototoxic in some cases, thus limiting their use. Kanamycin is a representative member of the aminoglycoside antibiotic family that shows multiple therapeutic applications and contains a 3-amino-3-deoxy-D-glucose moiety as a structural unit (Scheme 1).

In general, substitution of an $\mathrm{OH}$ group by a fluorine atom is an important resource in medicinal chemistry. ${ }^{2}$ In addition to the bioavailability issue, the fluorination of bioactive molecules can increase their biological activity and improve their lipid permeability and metabolic stability. Furthermore, it is known that the presence of fluorine in the carbohydrate moiety contained in aminoglycoside antibiotics reduces their toxicity, especially when the fluorine atom is adjacent to the amino group. Among a large number of strategies or agents to introduce fluorine into carbohydrates, diethylaminosulfur trifluoride (DAST) is commonly used for the direct replacement of a hydroxyl group by fluorine under very mild conditions. ${ }^{3,4}$

With the aim of developing a potentially efficient route to fluorinated kanamycin, we set out to synthesize the 3-amino-3-deoxy-D-glucose moiety and study its subsequent fluorination with DAST at position 2. Therefore, as a previous step of kanamycin synthesis, the formation of 3amino-3-deoxy-D-glucose from commercial available products has to be carried out. Condensation of phenylhydrazine with the sugar-derived dialdehyde $\mathbf{2}$ in water, as a key step, has been used ${ }^{5}$ as an elegant and simple synthetic strategy (Scheme 1).

We have revisited this process and we report herein new structural NMR and IR data of compounds $\mathbf{2}$ and $\mathbf{4}$ as well as a simple theoretical model for explaining the result of the key condensation process. In addition to this, we describe novel improved reaction conditions and our recent progress toward 2-fluorinated 3-amino-3-deoxy-D-glucose.

The synthesis of methyl 4,6-O-benzylidene-3-deoxy-3phenylazo- $\alpha$-D-glucopyranoside (4) was carried out in water by using phenylhydrazine. ${ }^{5}$ It has been proposed that, in aqueous solution, an equilibrium (Scheme 2) exists between the dialdehyde $\mathbf{2}$ and the hemialdal $\mathbf{3}$, obtained by periodate oxidation of methyl 4,6-Obenzylidene- $\alpha$-D-glucopyranoside (1). This reaction was carried out for a week at room temperature (Table 1, method A) in aqueous solution to obtain the oxidized product in $70 \%$ yield, but this proved irreproducible. When we used sodium periodate in a $\mathrm{MeOH}-\mathrm{H}_{2} \mathrm{O}$ mixture to accelerate the reaction (Table 1, method $\mathrm{B}$ ), a white solid, oxidized product was obtained in $98 \%$ yield. ${ }^{6}$

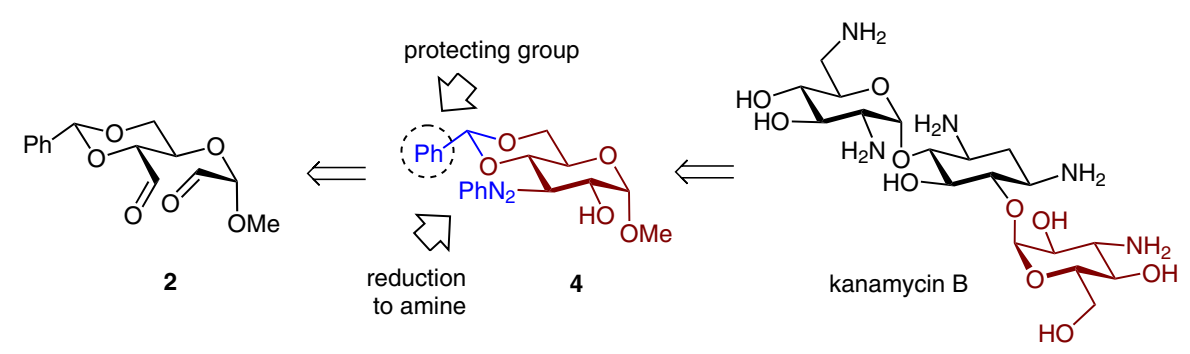

Scheme 1

SYNLETT 2013, 24, 0249-0253

Advanced online publication: 11.12 .2012

DOI: 10.1055/s-0032-1317783; Art ID: ST-2012-D0925-L

(C) Georg Thieme Verlag Stuttgart · New York 

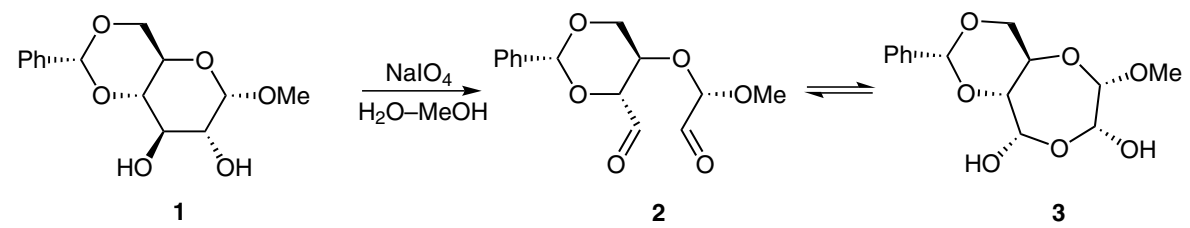

Scheme 2

Table 1 Reaction Conditions to Obtain Dialdehyde 2 or Hemialdal 3

\begin{tabular}{llrll}
\hline Method & Solvent & Time & Other conditions & Yield (\%) \\
\hline A & $\mathrm{H}_{2} \mathrm{O}$ & $1 \mathrm{w}$ & darkness & 70 \\
B & $\mathrm{MeOH}-\mathrm{H}_{2} \mathrm{O}$ & $20 \mathrm{~h}$ & darkness, cooling & 98 \\
\hline
\end{tabular}

We have performed IR spectra of compounds obtained by using both methods (Scheme 2, Table 1) and we did not observe a carbonyl absorption (ca. $1600 \mathrm{~cm}^{-1}$ ) in either case. This indicates that the periodate oxidation product of compound 1 has the structure of the hemialdal 3 . Furthermore, the product obtained by the periodate method showed ${ }^{1} \mathrm{H}$ NMR and ${ }^{13} \mathrm{C}$ NMR spectra (in DMSO- $d_{6}$ ) with no signals for the aldehydic protons nor carbonyl carbons, respectively. This information reinforced the hemialdal structure $\mathbf{3}$ assigned to the periodate oxidation product of compound 1, not only in the solid state as deduced from the IR spectrum, but also in solvents other than water, since the equilibrium between $\mathbf{2}$ and $\mathbf{3}$ occurs only in aqueous solution.

Therefore, we used $\mathrm{D}_{2} \mathrm{O}$ as the solvent for recording the ${ }^{1} \mathrm{H}$ NMR spectrum of compound 3 under presaturation conditions; in this case, the aldehydic proton signal was clearly observed at $\delta=9.97 \mathrm{ppm}$. Analogously, the aldehydic carbonyl signal appeared in the ${ }^{13} \mathrm{C}$ NMR spectrum (in $\mathrm{D}_{2} \mathrm{O}$ ) at $\delta=196.8 \mathrm{ppm}$ [other relevant signals: $\delta=$
135.5-126.4 ppm (aromatic carbons), 101.2 ppm ( $\mathrm{PhCH})$, $96.6 \mathrm{ppm}(\mathrm{C}-1)$, and $\left.48.9 \mathrm{ppm}\left(\mathrm{CH}_{3}\right)\right]$, confirming the presence of the dialdehyde $\mathbf{2}$ in the sample.

Next, we have investigated the condensation reaction of phenylhydrazine with dialdehyde $\mathbf{2}$ to obtain compound $\mathbf{4}$ (Scheme 3). We have tried different reaction conditions as indicated in Table 2.

Under the conditions studied, the results were not reproducible. Regarding compound 4, the best results were obtained using conditions A and E (Table 2). ${ }^{7}$ From the ${ }^{1} \mathrm{H}$ NMR spectrum we realized that the crude product obtained under conditions A (Table 2) was a 3:1 mixture of compounds $\mathbf{4}$ and $\mathbf{4 a}$. The presence of both regioisomers could be inferred from the two diagnostic signals for the anomeric OMe groups at $\delta=3.50$ and $3.52 \mathrm{ppm}$, and two singlets corresponding to $\mathrm{H}-7$ of the benzylidene groups at $\delta=5.77$ and $5.74 \mathrm{ppm}$.

Recrystallization of the crude solid product obtained under conditions E (Table 2), ${ }^{7}$ which was carried out under argon atmosphere and absence of light, afforded highly pure 4. Its ${ }^{1} \mathrm{H}$ NMR spectrum $\left(300 \mathrm{MHz}, \mathrm{CDCl}_{3}\right)$ included aromatic proton signals $(10 \mathrm{H})$ at $\delta=7.74-7.29 \mathrm{ppm}$, two singlets at $\delta=5.77$ and $3.50 \mathrm{ppm}$, respectively, assigned to the benzylic (H-7) and OMe protons, a broad singlet at $\delta=4.72 \mathrm{ppm}$ (anomeric proton), two triplets at $\delta=5.48$ $(10.2 \mathrm{~Hz})$ and $4.10 \mathrm{ppm}(10.0 \mathrm{~Hz}, \mathrm{H}-3$ and $\mathrm{H}-4)$, and a
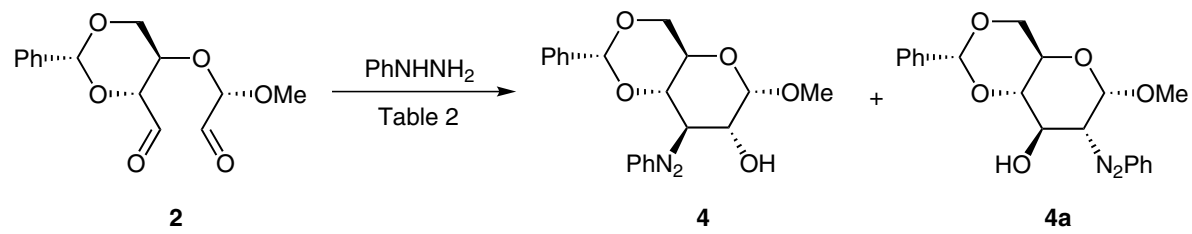

Scheme 3

Table 2 Reaction of Phenylhydrazine with Dialdehyde 2

\begin{tabular}{llllll}
\hline Conditions & Temp $\left({ }^{\circ} \mathrm{C}\right)$ & Reagent & Reagent (equiv) & Other conditions & Products (yield, \%) \\
\hline $\mathrm{A}$ & 85 & $\mathrm{PhNHNH}_{2}$ & 1.5 & - & $\mathbf{4}(15)+\mathbf{4 a}(7)$ \\
$\mathrm{B}$ & 80 & $\mathrm{PhNHNH}_{2}$ & 2.5 & not cooling & $\mathbf{5}(78)$ \\
$\mathrm{C}$ & 70 & $\mathrm{PhNHNH}_{3} \mathrm{Cl} / \mathrm{NaOAc}$ & 2 & darkness, ice $\left(0^{\circ} \mathrm{C}\right)$ & $\mathbf{5}\left(-{ }^{\mathrm{b}}\right)$ \\
$\mathrm{D}$ & 83 & $\mathrm{PhNHNH}_{2}$ & 2.5 & ice $/ \mathrm{NaCl}\left(-15^{\circ} \mathrm{C}\right)$ & $\mathbf{5}(68)$ \\
$\mathrm{E}$ & 92 & $\mathrm{NaOAc}^{\mathrm{P}} \mathrm{PhNHNH}_{3} \mathrm{Cl}$ & 2 & darkness, ice $/ \mathrm{NaCl}\left(-15^{\circ} \mathrm{C}\right), \operatorname{argon}$ & $\mathbf{4}(16)$ \\
\hline
\end{tabular}

${ }^{a}$ After recrystallization.

${ }^{\mathrm{b}}$ Not quantified, only detected by TLC. 
double doublet at $\delta=4.75 \mathrm{ppm}\left({ }^{3} J_{1,2}=4.5 \mathrm{~Hz}\right)$, assigned to $\mathrm{H}-2$.

Nevertheless, compound $4\left[R_{f}=0.88\left(49: 1 \mathrm{CH}_{2} \mathrm{Cl}_{2}\right.\right.$-acetone)], was unstable, and its rapid decomposition into products of lower $R_{f}$ was observed by TLC. Additionally, the low yields obtained for this compound could be explained by a competitive acid hydrolysis of $\mathbf{2}$ at the anomeric position in the aqueous medium to give 2,4-Obenzylidene-D-erythrose and glyoxal, which subsequently reacted with excess phenylhydrazine to afford glyoxal bisphenylhydrazone 5 (Figure 1). This compound, a useful product as promoter for metal-catalyzed cross-coupling reactions, ${ }^{8}$ was isolated in most conditions (conditions B, $\mathrm{C}$, and D, Table 2) as an orange solid and identified according to the literature. ${ }^{5}$

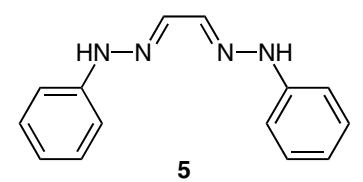

Figure 1

To justify the higher proportion of isomer 4 , we used a simple theoretical model with ChemBio3D and Discovery Studio 3.1. First, we applied an energy-minimization calculation using MM2 field force. Aromatic stacking interactions are widespread in nature, generally in biomolecules (e.g., DNA). In this context, two aromatic residues are considered to interact if the distance between phenyl centroids is less than $7 \AA .{ }^{9}$ From our calculations, a stacking interaction between the two phenyl groups present in the molecule of $\mathbf{4}$ was indicated (Figure 2). By using the same conditions to minimize energy, we observed an increased theoretical energy in the isomer $\mathbf{4 a}$, since the additional stabilization $\left(-12.1 \mathrm{~kJ} \mathrm{~mol}^{-1}\right)$ of an aromatic stacking interaction is not possible in this case.

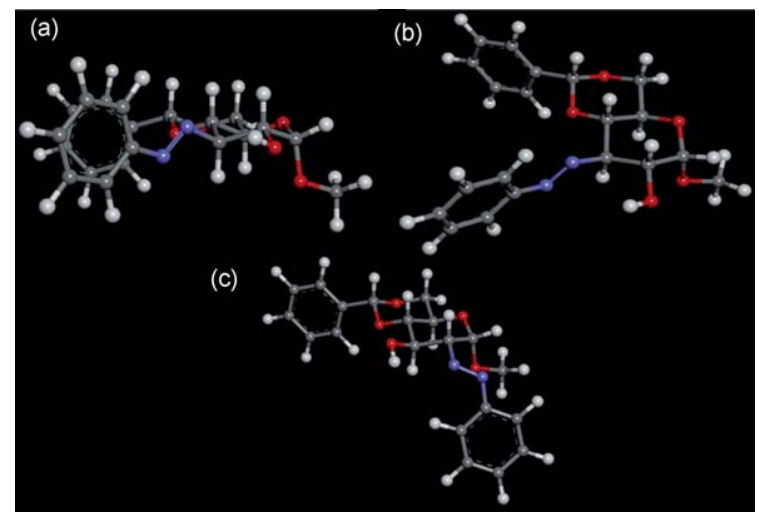

Figure 2 Modeling results: (a) isomer $\mathbf{4}$ showing aromatic interaction between aromatic ring residues, and (b) isomer $\mathbf{4}$ showing integrity of carbohydrate chair; (c) isomer $\mathbf{4 a}$ where aromatic interaction is not observed

Additionally, molecular-dynamics calculations ${ }^{10}$ were performed for isomers $\mathbf{4}$ and $\mathbf{4 a}$. In our simulation, the tar- get temperature was held at $300 \mathrm{~K}$, and the step and frame intervals were 2.0 and $10 \mathrm{fs}$, respectively. With this information, we could build a model for isomer interaction to check that aromatic stacking is not broken (Figure 3).

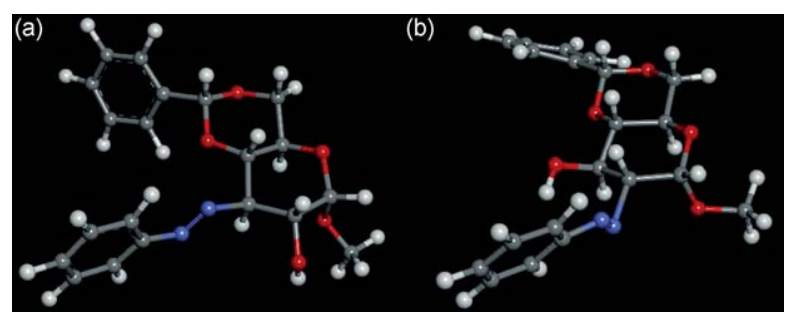

Figure 3 (a) Model of isomer 4, and (b) model of isomer $4 \mathbf{a}$ based on MD calculations

Crude compound 4 obtained under conditions E (Table 2) was reduced in $\mathrm{MeOH}$ by hydrogen in the presence of Adam's catalyst $\left(\mathrm{PtO}_{2}\right)$ to give methyl 3-amino-4,6-O-benzylidene-3-deoxy- $\alpha$-D-glucopyranoside (6) in quantitative yield pure enough to be used for further transformation, but too unstable to be purified by column chromatography (Scheme 4).

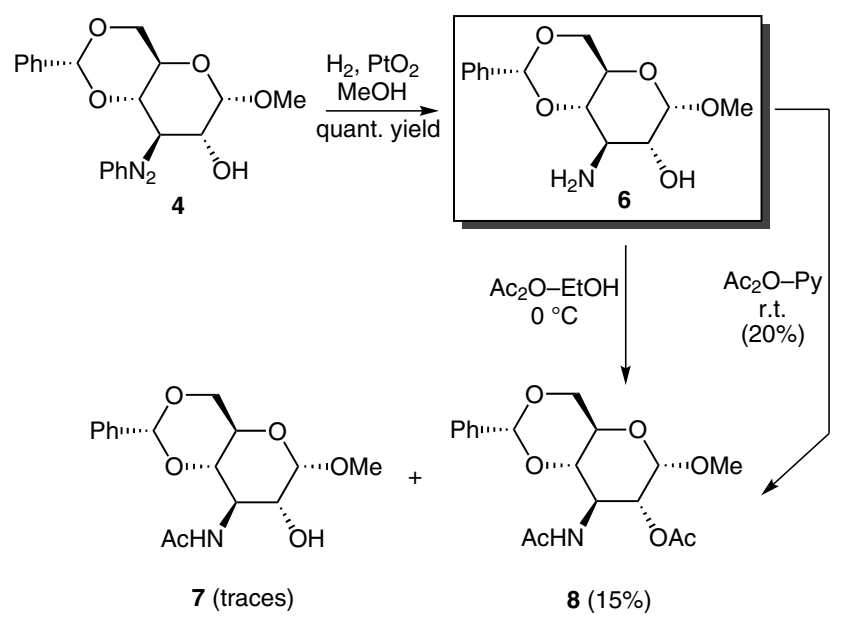

Scheme 4

Prior to the 2-OH fluorination of compound $\mathbf{6}$, we considered the possibility of selective protection of the 3-amino group by acetylation under the mild conditions described by Sharma et al. ${ }^{11}$ for related compounds. Under these conditions $\left(\mathrm{Ac}_{2} \mathrm{O}-\mathrm{EtOH}, 0{ }^{\circ} \mathrm{C}\right.$, Scheme 4$)$, only trace amounts of the 3 -acetamido compound 7 were obtained along with the 2,3-N,O-diacetate 8 in poor yield (15\%). Moreover, conventional acetylation in $\mathrm{Ac}_{2} \mathrm{O}$-pyrdine of compound $\mathbf{6}$ also turned out to be ineffective, with 8 being isolated in $20 \%$ yield.

All these compounds presented characteristic ${ }^{1} \mathrm{H}$ NMR features; the anomeric protons displayed a coupling constant ${ }^{3} J_{1,2}=4.5 \mathrm{~Hz}$, in agreement with that expected for $\alpha$ anomers, and a singlet was observed at $\delta=c a .4 .5 \mathrm{ppm}$ corresponding to the anomeric $\mathrm{OMe}$. 


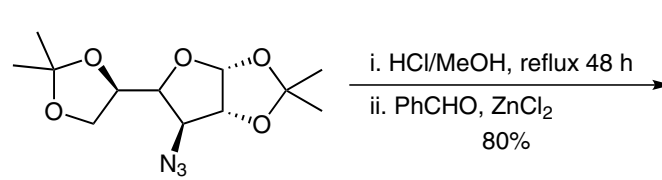

9

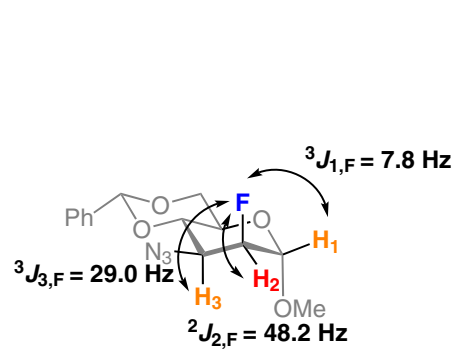<smiles>CO[C@H]1O[C@@H]2CO[C@@H](c3ccccc3)O[C@H]2[C@H](N)[C@H]1O</smiles>

10<smiles>CC(C)[C@H]1OCC2OC([O-])[C@H](O)C(N)C2O1</smiles>

$2: 1$

11

DAST

MeCN, reflux

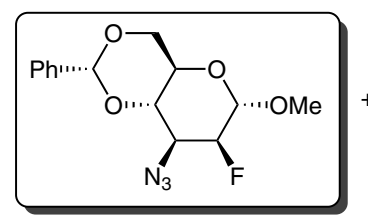

$12(25 \%)$

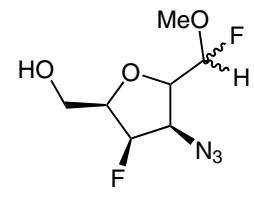

$13+14(63 \%)$

Scheme 5 Alternative synthetic route to fluorinated aminoglycoside derivatives and coupling constants of compound 12

While these reactions constitute a highly stereo- and regioselective route toward aminoglycosides that can be considered an example of a green chemistry strategy ${ }^{12}$ the lack of reproducibility and low yields made it necessary to seek alternative synthesis routes to 3-amino-3-deoxy-Dglucose $^{13}$ (Scheme 5).

Accordingly, hydrolysis of the diacetal $9^{14}(\mathrm{HCl}-\mathrm{MeOH}$, reflux, $7 \mathrm{~h}$ ) followed by the conventional protection of the 4- and 6-OH functions as a benzylidene acetal gave the anomeric 2:1 mixture of $\mathbf{1 0} / \mathbf{1 1}$, whose spectroscopic data were identical to those previously described in the literature. ${ }^{13 a}$ After separation by column chromatography, the major $\alpha$-D-anomer 10 was dissolved in $\mathrm{MeCN}$ and treated with DAST under reflux for six hours. Workup and purification by column chromatography on silica gel led to the desired pure 2-fluorinated compound 12 (25\%), ${ }^{15}$ along with a diastereomeric mixture of rearranged, ring-contracted products 13 and $\mathbf{1 4}(63 \%)^{4}$ and unreacted starting material $10(9 \%)$.

Usually, in ${ }^{1} \mathrm{H}$ NMR spectra of fluorinated sugars, the geminal coupling constants $\left({ }^{2} J_{\mathrm{F}, \mathrm{H}}\right)$ are $43-59 \mathrm{~Hz}$ in pyranoses and $46-66 \mathrm{~Hz}$ in furanose rings. ${ }^{16}$ The vicinal coupling constants $\left({ }^{3} J_{\mathrm{F}, \mathrm{H}}\right)$ depend on the electronegativity of neighboring substituents. In our case, the observed ${ }^{2} J_{2, \mathrm{~F}}=$ $48.2 \mathrm{~Hz}$ and ${ }^{3} J_{3, \mathrm{~F}}=29.0 \mathrm{~Hz}$ values are in agreement with the proposed structure 12. The required disposition of the hydrogen atoms on the ${ }^{4} C_{1}$ pyranose conformation for these coupling constants is shown in Scheme 5.
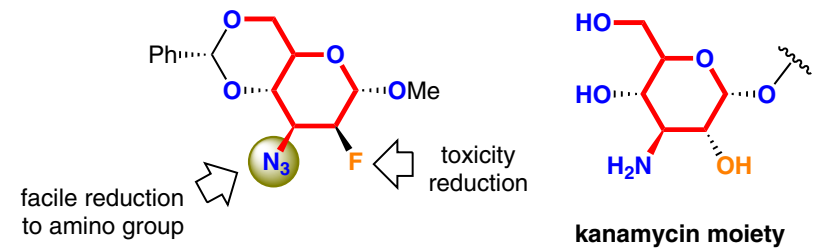

kanamycin moiety
Compound 12, having the backbone of an important moiety of kanamycin and a fluorine atom at C-2, presents a suitable feature to potentially reduce the toxicity of this aminoglycoside antibiotic. This compound has a latent amino functionality, the azide group, reduction of which would lead to the desired amine after hydrolysis of the benzylidene group (Figure 4).

The azide group could be readily reduced with hydrogen in the presence of $\mathrm{Pd} / \mathrm{C}$ catalyst or by Staudinger reaction with triphenylphosphine, and the benzylidene group could be hydrolyzed in a mixture $\mathrm{AcOH}-\mathrm{H}_{2} \mathrm{O}(7: 3)^{17}$ or $p$-toluenesulfonic acid. ${ }^{18}$

In summary, the aqueous condensation of phenylhydrazine and the dialdehyde obtained by periodate oxidation of methyl 4,6-O-benzylidene- $\alpha$-D-glucopyranoside (1), described in the literature as an elegant and easy synthesis of the corresponding 3-amino-3-deoxy derivative 6, has poor reproducibility in our hands. Spectroscopic studies and a simple theoretical model based on energy-minimization and molecular-dynamics calculations support the stereo- and regioselectivity of the process in favor of the 3-phenylazo isomer 4. In view of our unsuccessful efforts to improve the reproducibility and viability of this approach toward fluorinated kanamycin, we present the preparation of fluorinated precursor subunit 12 starting from commercially available diacetone-D-glucose, via the 3-azido-3-deoxy derivative 9.

\section{Acknowledgment}

We thank the AECID (Projects A/023577/09 and A/030422/10) and the 'Junta de Andalucía' (FQM 142 and Project P09-AGR-4597) for financial support. We also thank D. Lara for invaluable collaboration.

\section{References and Notes}

(1) (a) Li, J.; Chang, T. Anti-Infect. Agents Med. Chem. 2006, 5, 255. (b) Corey, E. J.; Czakó, B.; Kürti, L. Molecules and Medicine; John Wiley and Sons: Hoboken, 2007. 
(2) Kirk, K. L. Org. Process Res. Dev. 2008, 12, 305.

(3) Ferret, H.; Déchamps, I.; Gomez Pardo, D.; Van Hijfte, L.; Cossy, J. ARKIVOC 2010, (viii) 1, 26.

(4) Vera-Ayoso, Y.; Borrachero, P.; Cabrera-Escribano, F.; Carmona-Asenjo, A.; Gómez-Guillén, M. Tetrahedron: Asymmetry 2004, 15, 429; and references cited therein.

(5) Patroni, J.; Stick, R. Aust. J. Chem. 1985, 38, 947; and references cited therein.

(6) Synthesis of Compound 2 (Method B)

$\mathrm{NaIO}_{4}(7.7 \mathrm{~g}, 36 \mathrm{mmol})$ was dissolved in $\mathrm{H}_{2} \mathrm{O}(95 \mathrm{~mL})$. After cooling at $5{ }^{\circ} \mathrm{C}$, a solution of methyl 4,6- $O$-benzylidene- $\alpha$-Dglucopyranoside $(5 \mathrm{~g}, 17.73 \mathrm{mmol})$ in $\mathrm{MeOH}(95 \mathrm{~mL})$ was added. The mixture was stirred in the dark for $20 \mathrm{~h}$ at r.t. $\mathrm{EtOH}$ was added to precipitate iodates, and the filtered solution was evaporated under vacuum and dried to obtain dialdehyde 2 (98\% yield). ${ }^{13} \mathrm{C}$ NMR $\left(125.7 \mathrm{MHz}, \mathrm{D}_{2} \mathrm{O}\right): \delta=$ $196.8(\mathrm{CHO}), 135.5-126.4(\mathrm{Ph}), 101.2(\mathrm{CHPh}), 96.6(\mathrm{C}-1)$, $75.9(\mathrm{C}-4), 71.3(\mathrm{C}-6), 64.6(\mathrm{C}-5), 48.9\left(\mathrm{OCH}_{3}\right) \mathrm{ppm}$. HRMS (CI): $m / z$ calcd for $\mathrm{C}_{13} \mathrm{H}_{15} \mathrm{O}_{5}$ [M-CHO]: 251.0919; found: 251.0913; and $m / z$ calcd for $\mathrm{C}_{13} \mathrm{H}_{13} \mathrm{O}_{5}$ [M-OMe]: 249.0763; found 249.0766.

(7) Preparation and Most Relevant Data of Compound 4 Conditions $\mathbf{A}^{\mathbf{5}}$

Phenylhydrazine ( $250 \mu \mathrm{L}, 2.59 \mathrm{mmol})$ was added to a solution of compound $2(0.5 \mathrm{~g}, 1.79 \mathrm{mmol})$ in $\mathrm{H}_{2} \mathrm{O}(125 \mathrm{~mL})$ at $85{ }^{\circ} \mathrm{C}$. On shaking the yellow mixture rapidly with icewater, a yellow solid precipitated. This crude product was filtered off and purified by recrystallization from a small volume of butan-1-ol to give a yellow solid, identified as a mixture of $4(95.2 \mathrm{mg}, 15 \%)$ and $\mathbf{4 a}(27.7 \mathrm{mg}, 7 \%)$.

Attempted column chromatography on silica gel resulted in rapid decomposition.

\section{Conditions E}

A solution of compound $2(0.33 \mathrm{~g}, 1.18 \mathrm{mmol})$ in $\mathrm{H}_{2} \mathrm{O}(100$ $\mathrm{mL})$ was heated at $92{ }^{\circ} \mathrm{C}$, under argon in darkness. The solution was cooled, then $\mathrm{NaOAc}(0.39 \mathrm{~g}, 4.73 \mathrm{mmol})$ was added followed by slow addition of phenylhydrazine hydrochloride ( $0.34 \mathrm{~g}, 2.36 \mathrm{mmol})$. After rapid cooling to $15^{\circ} \mathrm{C}$ and shaking of the mixture, a yellow solid precipitated. This product was filtered off, washed with cool $\mathrm{H}_{2} \mathrm{O}$, recrystallized from butan-1-ol and dried under vacuum to give a yellow solid which was identified as pure methyl 4,6-O-benzylidene-3-deoxy-3-phenylazo- $\alpha$-Dglucopyranoside $(4,68.6 \mathrm{mg}, 16 \%) . R_{f}=0.88\left(\mathrm{CH}_{2} \mathrm{Cl}_{2}-\right.$ acetone $=49: 1)$.

${ }^{1} \mathrm{H}$ NMR $\left(300 \mathrm{MHz}, \mathrm{CDCl}_{3}\right): \delta=7.74-7.29(\mathrm{~m}, 10 \mathrm{H}, \mathrm{Ph})$, $5.77(\mathrm{~s}, 1 \mathrm{H}, \mathrm{H}-7), 5.48\left(\mathrm{t}, 1 \mathrm{H}, \mathrm{H}-3, J_{3,4}=J_{3,2}=10.2 \mathrm{~Hz}\right)$, $4.75\left(\mathrm{dd}, 1 \mathrm{H}, \mathrm{H}-2, J_{2,1}=4.5, J_{2,3}=10.6 \mathrm{~Hz}\right), 4.72(\mathrm{br} \mathrm{s}, 1 \mathrm{H}$, $\mathrm{H}-1), 4.46\left(\mathrm{dd}, 1 \mathrm{H}, J_{6 \mathrm{ec}, 5}=4.6 \mathrm{~Hz}, J_{6 \mathrm{ec}, 6 \mathrm{ax}}=10.2 \mathrm{~Hz}, \mathrm{H}-6_{\mathrm{eq}}\right.$ ), $3.32\left(\mathrm{~m}, 2 \mathrm{H}, \mathrm{H}-5\right.$ and $\left.\mathrm{H}-6_{\mathrm{ax}}\right), 4.10\left(\mathrm{t}, 1 \mathrm{H}, \mathrm{H}-4, J_{4,3}=J_{4,5}=\right.$ $10.0 \mathrm{~Hz}$ ), 3.50 (s, $3 \mathrm{H}, \mathrm{OCH}_{3}$ ) ppm. HRMS (CI): $\mathrm{m} / z$ calcd for $\mathrm{C}_{20} \mathrm{H}_{22} \mathrm{~N}_{2} \mathrm{O}_{5}: 370.1529$; found: 370.1522 .

(8) (a) Liu, Y.-H.; Li, G.; Yang, L.-M. Tetrahedron Lett. 2009, 50,343. (b) Trofimov, B. A.; Myachina, G. F.; Ermakova, T. G.; Kuznetsova, N. P.; Volkova, L. I.; Sultangareev, R. G.;
Larina, L. I.; Klyba, L. V.; Sukhanov, G. T.; Sakovich, G. V. Russ. J. Org. Chem. 2009, 45, 1683.

(9) Hunter, C. A.; Lawson, K. R.; Perkins, J.; Urch, C. J. J. Chem. Soc., Perkin Trans. 2 2001, 651.

(10) (a) Rode, M. B.; Hofer, S. T.; Kugler, D. M. The Basics of Theoretical and Computational Chemistry; Wiley-VCH: Weinheim, 2007. (b) Young, D. Computational Chemistry; John Wiley and Sons: New York, 2001.

(11) Sharma, M.; Bernacki, R. J.; Hillman, M. J.; Korytnyk, W. Carbohydr. Res. 1993, 240, 85 .

(12) Anastas, Y.; Warner, J. C. Green Chemistry: Theory and Practice; Oxford University Press: New York, 1998.

(13) (a) Albert, R.; Dax, K.; Pleschko, R.; Stutz, A. E. Carbohydr. Res. 1985, 137, 282. (b) Faghih, R.; CabreraEscribano, F.; Castillon, S.; Garcia, J.; Olesker, A.; That Thang, T. J. Org. Chem. 1986, 51, 4558.

(14) Brimacombe, J. S.; Bryan, J. G. H.; Husain, A.; Stacey, M.; Tolley, M. S. Carbohydr. Res. 1967, 3, 318.

(15) Preparation of Compound 12 A solution of compound $\mathbf{1 0}(109 \mathrm{mg}, 0.355 \mathrm{mmol})$ in dry $\mathrm{MeCN}(6.5 \mathrm{~mL})$ was treated with DAST $(236 \mu \mathrm{L}, 1.785$ $\mathrm{mmol})$ at $0{ }^{\circ} \mathrm{C}$ under argon. After several minutes, the cooling bath was removed, and the mixture was heated to reflux for $6 \mathrm{~h}$, monitoring the reaction by TLC. On completion, after evaporation of the solvent, the residue was treated with $\mathrm{CH}_{2} \mathrm{Cl}_{2}(20 \mathrm{~mL})$ and cold sat. aq $\mathrm{NaHCO}_{3}(50$ $\mathrm{mL})$. The aqueous layer was extracted with $\mathrm{CH}_{2} \mathrm{Cl}_{2}(3 \times 20$ $\mathrm{mL}$ ), and the combined organic layers were washed with sat. aq $\mathrm{NaCl}(50 \mathrm{~mL})$, dried $\left(\mathrm{Na}_{2} \mathrm{SO}_{4}\right)$, filtered, and concentrated. The residue was purified by column chromatography on silica gel $\left(1: 5\right.$ to $1: 3$ gradient hexane- $\mathrm{Et}_{2} \mathrm{O}$ with $\left.1 \% \mathrm{Et}_{3} \mathrm{~N}\right)$ to give unreacted $10(9 \%)$, compound $12(25 \mathrm{mg}$, corresponding to $25 \%$ yield from converted substrate) and the epimeric mixture $\mathbf{1 3} / \mathbf{1 4}$ [63\% yield, characterized by transformation into the corresponding $(1 R$ and $1 S)-2,5$ anhydro-3-azido-6-O-tert-butyl-diphenylsilyl-3,4-dideoxy1,4-difluoro-1-O-methyl-D-talitols. $\left.{ }^{4}\right]$

\section{Selected Analytical Data}

Compound 12: solid; $\mathrm{mp} 56-60^{\circ} \mathrm{C} ; R_{f}=0.44\left(\mathrm{Et}_{2} \mathrm{O}-\right.$ hexane $=1: 3) .{ }^{1} \mathrm{H}$ NMR $\left(300 \mathrm{MHz}, \mathrm{CD}_{3} \mathrm{COCD}_{3}\right): \delta=7.49-7.36(\mathrm{~m}$, $5 \mathrm{H}, \mathrm{Ph}), 5.81(\mathrm{~s}, 1 \mathrm{H}, \mathrm{CHPh}), 4.91\left(\mathrm{dd}, 1 \mathrm{H},{ }^{3} J_{1, \mathrm{~F}}=7.8 \mathrm{~Hz}\right.$, $J_{1,2}=1.7 \mathrm{~Hz}, \mathrm{H}-1$ ), 4.78 (ddd, $1 \mathrm{H},{ }^{2} J_{2, \mathrm{~F}}=48.2 \mathrm{~Hz}, J_{2,3}=2.3$ $\mathrm{Hz}, \mathrm{H}-2), 4.27$ (dd, $1 \mathrm{H}, J_{6,6^{\prime}}=11.7 \mathrm{~Hz}, J_{5,6}=1.7 \mathrm{~Hz}, \mathrm{H}-6$ ), 4.12 (ddd, $1 \mathrm{H}, J_{3,4}=10.6 \mathrm{~Hz}, J_{4,5}=9.0 \mathrm{~Hz},{ }^{4} J_{4, \mathrm{~F}}=1.6 \mathrm{~Hz}$, $\mathrm{H}-4$ ), 3.92 (ddd, $\left.{ }^{3} J_{3, \mathrm{~F}}=29.0 \mathrm{~Hz}, \mathrm{H}-3\right), 3.89-3.83$ (m, $2 \mathrm{H}, \mathrm{H}-$ 5 and $\left.\mathrm{H}-6^{\prime}\right), 3.44\left(\mathrm{~s}, 3 \mathrm{H}, \mathrm{OCH}_{3}\right) \mathrm{ppm} .{ }^{13} \mathrm{C} \mathrm{NMR}(75.8 \mathrm{MHz}$, $\left.\mathrm{CD}_{3} \mathrm{COCD}_{3}\right): \delta=138.8-127.2(\mathrm{Ph}), 102.5(\mathrm{CHPh}), 99.5(\mathrm{~d}$, $\left.{ }^{2} J_{\mathrm{C} 1, \mathrm{~F}}=31.0 \mathrm{~Hz}, \mathrm{C}-1\right), 89.8\left(\mathrm{~d},{ }^{1} J_{\mathrm{C} 2, \mathrm{~F}}=180.0 \mathrm{~Hz}, \mathrm{C}-2\right), 74.6$ $(\mathrm{C}-4), 69.2(\mathrm{C}-6), 64.9(\mathrm{C}-5), 59.7\left(\mathrm{~d},{ }^{2} J_{\mathrm{C} 3 \mathrm{~F}}=16.6 \mathrm{~Hz}\right), 55.7$ $\left(\mathrm{OCH}_{3}\right)$ ppm. HRMS (CI): $m / z$ calcd for $\mathrm{C}_{14} \mathrm{H}_{16} \mathrm{FN}_{3} \mathrm{O}_{4}+\mathrm{H}$ : 310.1203; found: 310.1207 .

(16) Michalik, M.; Hein, M.; Frank, M. Carbohydr. Res. 2000, 327,185 .

(17) Baer, H. H.; Gan, Y. Carbohydr. Res. 1991, 210, 233.

(18) Vera-Ayoso, Y.; Borrachero, P.; Cabrera-Escribano, F.; Gómez-Guillén, M.; Caner, J.; Farrás, J. Synlett 2010, 271. 